\title{
ANALISA STRATEGI PENGEMBANGAN BISNIS PT TANABE INDONESIA DALAM MENGAHADAPI ERA JAMINAN KESEHATAN NASIONAL
}

\author{
Midyan Aji Arso \\ Program Studi Magister Manajemen Universitas Tarumanagara \\ midyanaji@gmail.com
}

Masuk : 07-12-2019, revisi : 07-01-2020 diterima untuk diterbitkan : 07-01-2020

\begin{abstract}
This research was conducted to analyze the business development strategy of PT Tanabe Indonesia in the face of the JKN era, by describing the internal conditions such as Marketing, Finance, production and human resources and also external condition of companies, namely the five-force analysis. A SWOT analysis is used to identify the strengths, weaknesses, opportunities and threats. The study was conducted with a qualitative-descriptive method using primary and secondary data collection techniques through interviews, observation and identification of company documents. The results showed that the business development strategy in facing the JKN era carried out by PT Tanabe Indonesia was a focus strategy, namely focusing the company on narrower market segments and maintaining production efficiency and effectiveness.
\end{abstract}

Keywords : Five force analysis, SWOT Analysis, Jaminan Kesehatan Nasional (JKN), Competitive strategy.

Abstrak : Penelitian ini dilakukan untuk menganalisa strategi pengembangan bisnis PT Tanabe Indonesia dalam menghadapi era JKN, dengan cara mendeskripsikan kondisi lingkungan internal yaitu Pemasaran, Keuangan, produksi dan sumber daya manusia dan eksternal perusahaan yaitu five force analisis. Selanjutnya di lakukan analisa SWOT untuk mengidentifikasi keukatan, kelemahan, peluang dan ancaman. Penelitian dilakukan dengan metode kualitatif-deskriptif ini menggunakan teknik pengumpulan data primer dan sekunder melalui wawancara, observasi dan identifikasi dokumen perusahaan. Dari hasil penelitian disimpulkan bahwa strategi pengembgan bisnis dalam menghadapi era JKN yang dilakukan ole PT Tanabe Indonesia adalah strategi fokus, yaitu memfokuskan perusahaan pada segmen pasar yang lebih sempit serta menjaga efisiensi dan efektivitas produksi.

Kata Kunci : Analisa five force, Analisa SWOT, Jaminan Kesehatan Nasional (JKN), Strategi bersaing.

\section{PENDAHULUAN}

Persaingan yang ada pada suatu industri secara umum dipengaruhi oleh faktor internal perusahaan dan faktor eksternal dimana bisnis berada. Faktor internal akan dipengaruhi kuat oleh sumber daya dan kompetensi yang dimiliki oleh perusahaan, misalnya dalam hal penguasaan teknologi, proses produksi, logistik, pemasaran dan kemampuan distribusi perusahaan tersebut. Faktor lingkungan makro merupakan faktor di luar perusahaan yang terus berubah dan memberi dampak bagi perusahaan dan industri. Manajemen perusahaan harus dapat melihat dan memahami perubahan tersebut dan beradaptasi dengan perubahan dengan penyesuaian strategi perusahaan.

Mulai tahun 2004 pemerintah Indonesia mulai menjalankan SJSN (Sistem Jaminan Sosial Nasional) yang telah memperbaiki akses rakyat miskin ataupun hampir miskin terhadap pelayanan kesehatan. Pada tahun 2005 pemerintah mulai menjalankan program Askeskin yang telah dapat menjangkau hampir 40 juta rakyat miskin di Indonesia. Program ini terus 
berkembang dan mulai tahun 2014 pemerintah Indonesia menjalankan program Jaminan Kesehatan Nasional (JKN) yang diselenggarakan oleh BPJS Kesehatan. Program ini diharapkan akan dapat terus menjangkau masyarakat luas dan ditargetkan akan dapat memberikan jaminan kesehatan bagi seluruh masyarakat Indonesia pada awal tahun 2019. Terus meningkat nya jumlah peserta JKN ini yang tentunya memberi dampak langsung terhadap pertumbuhan pasar farmasi.

Dengan semakin bertambahnya jumlah peserta JKN dari tahun ke tahun, maka permintaan obat dari program JKN akan menjadi penopang kuat peningkatan kebutuhan pasar khususnya akan obat generik. Hal ini juga mungkin dapat menyebabkan pergeseran permintaan pasar dari obat paten menuju obat generik. Jorge Wagner, Ketua Umum International Pharmaceutical Manufacturers Group (IPMG) bahwa industri farmasi obat resep dokter di Indonesia akan terus mengalami peningkatan ditahun mendatang karena semakin banyaknya peserta JKN dan juga upaya dari pemerintah yang terus mendukung program JKN. Hal ini tentunya akan mengubah persaingan sekaligus juga strategi yang diterapkan oleh pelaku di industri farmasi yang semakin ketat di sektor non-JKN.PT Tanabe Indonesia merupakan perusahaan farmasi asal Jepang yang sudah lama berinvestasi di Indonesia yaitu sejak tahun 1970 dan tergabung dalam IPMG. Berdasarkan data-data dari PT Tanabe Indonesia tersebut bisa dilihat bahwa PT Tanabe Indonesia memperoleh hasil penjualan yang positif di Era JKN. Untuk itu, dalam penelitian ini akan di Analisa strategi pengembangan bisnis yang di terapkan oleh PT Tanabe Indonesia dalam menghadapai era JKN.

\section{Tujuan Penelitian :}

1. Menganalisa struktur perusahaan di PT. Tanabe Indonesia yang ada saat ini.

2. Mengidentifikasi dan menganalisis faktor-faktor yang menjadi driving force (Internal dan Eksternal) PT. Tanabe Indonesia menjelang berlakunya JKN secara penuh pada tahun 2020.

3. Mengidentifikasi faktor kunci sukses PT. Tanabe Indonesia.

\section{TINJAUAN PUSTAKA}

\section{Analisa Lingkungan Internal}

Di dalam bukunya, David (2011, p. 93) mengatakan bahwa terdapat beberapa kekuatan dalam lingkungan internal perusahaan, yang terdiri dari pemasaran, keuangan, produksi, dan sistem informasi manajemen. Sedangkan di dalam bukunya, Heizer dan Render (2014, p. 36) menyatakan bahwa organisasi terbagi menjadi pemasaran, keuangan, operasional. Senada dengan mereka, Stevenson (2012, p. 4) membagi organisasi menjadi sisi penawaran (supply) dan permintaan (demand), di mana sisi penawaran terdiri dari operasional, dan sisi permintaan terdiri pemasaran dan keuangan. Pemasaran Menurut David (2011, p. 103), pemasaran dapat dideskripsikan sebagai proses pendefinisian, pencegahan, penciptaan, dan pemenuhan kebutuhan dan keinginan pelanggan akan barang dan jasa. Senada dengan hal itu, Kotler dan Kotler (2012, p. 5) mengatakan bahwa pemasaran adalah mengenai mengidentifikasi dan mempertemukan kebutuhan manusia dan masyarakat. Sehingga dapat disimpulkan bahwa, pemasaran adalah proses pendefinisian, penciptaan, pemenuhan dan pertemuan antara kebututuhan dan keinginan manusia dan masyarakat akan barang dan jasa.

\section{Analisa Lingkungan Eksternal (Model Lima Kekuatan Porter)}

Analisa Persaingan Model Lima Kekuatan Porter merupakan pendekatan yang banyak dipakai untuk mengembangkan strategi oleh banyak industri. Intensitas antar perusahaan sangat beragam di berbagai industri. Menurut Porter, sifat persaingan dalam suatu industri dapat dilihat sebagai gabungan dari lima kekuatan berikut ini.

1. Perseteruan di Antara Perusahaan yang Bersaing

2. Potensi Masuknya Pesaing Baru 
3. Potensi Pengembangan Produk Pengganti

4. Kekuatan Tawar Pemasok

5. Kekuatan Tawar Konsumen

\section{Analisis SWOT}

Ritson (2008, p. 44) menjelaskan bahwa analisis SWOT pada dasarnya adalah analisis lingkungan internal dan eksternal perusahaan dengan berbasis kekuatan (Strength), kelemahan (Weakness), peluang (Opportunities), dan ancaman (Treath). Yang termasuk dalam lingkungan dalam analisis SWOT adalah kekuatan (Strength) dan kelemahan (Weakness). Sedangkan untuk lingkungan eksternal adalah peluang (Opportunities) dan ancaman (Treath) Berdasarkan pada berbagai pendapat tersebut, maka analisis SWOT terdiri dari dari empat kuadran (bagian) yang menjelaskan kekuatan perusahaan berdasarkan kekuatan sumberdaya internal perusahaan, mengidentifikasikan kelemahan perusahaan berdasarkan pada kelemahan.

\section{Penelitian Terdahulu}

Penelitian terdahulu yang relevan adalah sebagai berikut :

\begin{tabular}{|c|c|c|c|}
\hline Nama Peneliti & Judul Penelitian & Metode Analisis & Hasil Analisis \\
\hline $\begin{array}{l}\text { Imam Dwinanto } \\
\text { (2017). }\end{array}$ & $\begin{array}{l}\text { Analisis Industri Farmasi } \\
\text { Indonesia dalam mengahadi } \\
\text { Era BPJS (Jaminan Kesehatan } \\
\text { Nasional) }\end{array}$ & $\begin{array}{l}\text { Analisis Kualitatif } \\
\text { Deskriptif }\end{array}$ & $\begin{array}{l}\text { Faktor potensial yang menjadi driving force } \\
\text { di Industri } \\
\text { farmasi Indonesia adalah sebagai berikut: } \\
\text { Program JKN, Perubahan tingkat } \\
\text { pertumbuhan Industri Farmasi dan Inovasi } \\
\text { penduduk }\end{array}$ \\
\hline $\begin{array}{l}\text { Natalia Kolina } \\
\text { (2013) }\end{array}$ & $\begin{array}{lcr}\text { Analisa } & \text { deskriptif } & \text { strategi } \\
\text { bersaing } & \text { pada } & \text { indsutri } \\
\text { manufacturing plastik } & \end{array}$ & $\begin{array}{l}\text { Analisis Kualitatif } \\
\text { Deskriptif }\end{array}$ & $\begin{array}{l}\text { Dari penelitian dapat di ketahui bahwa } \\
\text { untuk saat } \\
\text { perusahaan masih bersaing di dalam } \\
\text { samudra merah (red } \\
\text { ocean strategy) dengan menerapkan Focus } \\
\text { differentiation } \\
\text { strategy pada pelanggan tertentu dengan } \\
\text { mengutamakan } \\
\text { kualitas produk dan Me Too strategy } \\
\text { dengan mengikuti } \\
\text { strategi yang digunakan pesaing }\end{array}$ \\
\hline $\begin{array}{l}\text { Zacky Riskaw } \\
(2017)\end{array}$ & $\begin{array}{l}\text { Analisis Strategi bersaing } \\
\text { Pfizer Indonesia di Era JKN }\end{array}$ & Deskriptif-Qualitative & $\begin{array}{l}\text { Tingkat persaingan industry di era JKN } \\
\text { sangat tinggi, Pfizer Indonesia memiliki } \\
\text { keunggulan kompetitive pada penelitian } \\
\text { dan pengembangan dalam memperkuat } \\
\text { kapbilitas menghasilkan inovasi produk } \\
\text { produk baru }\end{array}$ \\
\hline
\end{tabular}

\section{METODOLOGI}

Jenis penelitian ini adalah penelitian kualitatif - deskriptif, sebagaimana pendapat Creswell (2014, p. 232) bahwa metode kualitatif adalah metode yang mendasarkan pada teks dan image data, memiliki langkah analisis yang unik dan digambarkan dalam desain yang beragam. Teks dan image data merupakan data hasil serangkaian proses wawancara dan peneliti bisa memiliki penilaian yang subyektif terhadap setiap data yang diperoleh dari hasil wawancara sehingga tingkat kedalaman analisis bisa berbeda untuk setiap peneliti.

Dalam penelitian ini teknik pengumpulan data yang digunakan adalah wawancara, Identifikasi, Observasi Dokumentasi.

\section{HASIL DAN KESIMPULAN Analisis Strategi}

Strategi yang diterapkan selama ini oleh PT Tanabe Indonesia adalah strategi fokus pada segmentasi yang dimiliki perusahaan yakni segmen pasar obat etikal untuk terpai penyakit kardiovaskular dengan sasaran market branded atau originator. Perusahaan juga mengutamakan efisiensi produksi dan kualitas produk. Dilihat dari variasi produk yang dimiliki 
perusahaan belum banyak namun kualitasnya yang cukup tinggi sehingga perusahaan mampu bersaing di sektor BPJS dan regular. Hingga saat ini perusahaan memiliki pelanggan lebih dari 2000 rumah sakit (BPJS dan Regular) dan sekitar 700 dokter spesialis penyakit jantung sebagai pengguna produk PT Tanabe Indonesia. Strategi pemasaran yang selama ini digunakan perusahaan adalah strategi pemasaran langsung terjun ke pasar untuk memberikan informasi keunggulan dan manfaat produk kepada rumah sakit dan juga dokter spesialis jantung, serta untuk lebih mendekatkan dengan pelanggan. Disini PT Tanabe Indonesia menekankan keahlian dari para sales marketing untuk dapat memberikan penjelasan yang baik berdasarkan data-data ilmiah untuk meyakinkan pelanggan terhadap produk dan layanan perusahaan.

Produk yang di pasarkan terdaftar di BPJS, pengalaman di bidang penyakit kardiovaskular hampir 50 tahun, kualitas produk terjamin (standar Jepang). Namun di sisi lain perusahaan juga memiliki kelemahan diantaranya jumlah tenaga penjual kurang optimal, jumlah kantor cabang masih terbatas dan produk lama. Pada bagian lingkungan eksternal PT Tanabe Indonesia memiliki peluang dan ancaman, peluang dari PT Tanabe Indonesia yaitu; jumlah peserta BPJS yang terus bertambah, kenaikan iuran peserta BPJS dan prevalensi penyakit kardiovaskular terus meningkat. Untuk ancaman, PT Tanabe Indonesia memiliki ancaman antara lain; kebijakan pemerintah membatasi biaya rawat pasien BPJS, Persaingan ketat dengan industry sejenis, munculnya produk-produk terbaru atau pengganti. Perusahaan PT Tanabe Indonesia selalu memiliki rencana jangka pendek dan jangka Panjang untuk menghadapi ancaman dan memanfaat peluang.

Hal konkrit yang dilakukan PT Tanabe Indonesiadalam rencana jangka panjang adalah dengan pengembangan bisnis yaitu dengan memproduksi produk-produk baru yang di peroleh dari induk perusahaan di Jepang serta melakukan partnership dengan perusahaan dan pihakpihak yang ada di dalam negeri maupun di luar negeri untuk pasar domestik dan juga untuk memperluas pasar ke luar negeri (export).

Dengan melakukan partnership/penggandengan pihak-pihak lain juga bertujuan mempercepat pengembangan bisnis yaitu dengan mengakuisisi produk atau sebatas kerjasama dalam hal memasarakan atau co marketing. Dalam dua tahun terkahir PT Tanabe Indonesia berhasil berpatner dengan perusahaan asal Australia dengan penambahan omset atau revenue sekitar 120 miliar pertahun. Namun untuk saat ini dapat terlihat pencapain perusahaan sejak dimulainya era JKN 2014 hingga 2019, kondisi perkembangan dari perusahaan terus berjalan naik secara perlahan membuktikan bahwa dengan strategi dan reputasi yang dimiliki perusahaan, perusahaan dapat terus melakukan penjualan secara optimal. Penjualan yang dilakukan perusahaan tidak hanya dalam sektor BPJS akan tetapi juga memperkuat sektor regular. Dimana berdasarkan data dari salah satu perusahaan asuransi, pengguna atau peserta asuransi regular terus meningkat.

\section{Kesimpulan}

Berdasarkan data hasil analisis dan pembahasan yang telah dilakukan, dapat disimpulkan bahwa :

1. Lingkungan internal dari PT tanabe Indonesia yang meliputi divisi pemasaran, divisi Corporate planning yang di dalamnya terdapat Departemen pengembangan bisnis dan Departemen Keuangan, selanjutnya adalah divisi Administrative yang di dalamnya terdapat departemen Human resource dan General affair dan departemn IT, dan yang terkahir adalah Divisi manufacturing yang mencakup departemen produksi, supply chain, QA dan QC terdapat kekuatan dan kelemahan perusahaan. Kekuatan dari perusahaan antara lain adalah; Produk yang di pasarakan terdaftar di BPJS, Pengalaman di bidang penyakit kardiovaskular dan Kualitas produk terjamin (standar Jepang). Terdapat pula kelemahan dari perusahaan yaitu; Jumlah Tenaga penjual kurang optimal, Kantor cabang masih terbatas dan Produk lama

2. Lingkungan eksternal dari PT Tanabe Indonesia yaitu lingkungan industri. Lingkungan 
industri meliputi; ancaman pendatang baru, daya tawar pemasok, daya tawar konsumen, ancaman produk substitusi, dan persaingan dengan perusahaan sejenis. Faktor yang paling berdampak terhadap PT Tanabe Indonesia adalah faktor persaingan dengan perusahaan sejenis dan Ancaman produk subtitusi.

3. Strategi yang digunakan perusahaan saat ini merupakan strategi fokus yakni perusahaan memfokuskan diri pada segmentasi yang lebih sempit sehingga perusahaan mengambil peluang yang tidak disadari oleh para pesaingnya. Segmen pemasaran yang dimiliki perusahaan antara lain adalah segmen pasar yang berhubungan dengan penyakit kardiovaskuler dan juga segmen regular (non BPJS) Pencapaian persuahaan dari mulainya era JKN 2014 hingaa saat ini terlihat trend yang positive atau mengalami pertumbuhan dari tahun ke tahun, dapat disimpulkan bahwa strategi yang saat ini digunakan oleh perusahaan cukup baik dan dapat digunakan untuk melakukan persaingan yang ada dalam era JKN.

\section{DAFTAR PUSTAKA}

Arikunto, S. 2006. Prosedure Penelitian: Suatu Pendekatan Praktek. Jakarta: Rineka Cipta.

Creswell, J.W., 2014. Research Design: Qualitative, Quantitative, and mixed methods Approaches. Fourth Edistion. Los Angeles: Sage Publication Inc.

David, Fred R. (2011). Strategic management: Conceptand cases. Thirteenth edition. Boston: Prentice Hall Inc. Jakarta.

Indonesian Quarterly Pharma Market Update Q2. (2019, Juli). Report. IQVA.

Kementrian perindustrian tahun 2019, retrieved Mar 27, 2019: https://katadata.co.id/berita/2019/03/27/menperin-industri-farmasi-nasional-tumbuh446-tahun-lalu.

Kotler, Philip, dan Keller. 2009. Marketing Management, prentice hall, New Jersey.

Kriyantono, Rachmat. 2009. Teknik Praktis Riset Komunikasi. Jakarta: Kencana.

Laporan Akuntabilitas Kinerja tahun 2013, Kementrian perencaan pembangunan nasional. Retrieved Jan 2019, from http://ppid.bappenas.go.id/wpcontent/uploads/2018/08/Laporan-Kinerja-Tahun-2013.pdf.

Badan Pusat statistic. (2013). Proyeksi Penduduk Indonesia 2010-2035. Kementrian PPN/Bappenas-UN Population.

LKPP data. Retrieved data Sep 2019: https://ekatalog.lkpp.go.id/id/katalog/produk/obat2018/74?authenticityToken=0a7a0de1d695f3 $315327 \mathrm{ca}$ cad61d65fc8e46569\&cat=\&q=\&nama_produk=bisoprolol\&prid=\&pid=\&mi $\mathrm{d}=\& \mathrm{gt}=\& \mathrm{lt}=$

Moleong, Lexy. J. 2011. Metodologi Penelitian Kualitatif. PT Remaja Rosdakarya, Bandung. Porter. M.E. (2008). The Five Competitive Forces That Shape Strategy. Harvard Business Review, Januari 78-93.

Porter, M. E. (1985). Competitive advantage: Creating and Sustaining Superior Peformance, $1^{\text {st }}$ edition. New York: The Free Press.

Standard chatter bank, retrieved data: http/ standard/belanja/kesehatan.

Sugiyono. 2012.Metode Penelitian Pendidikan (Pedekatan Kuantitatif, Kualitatif dan R\&D). CV Alfabeta, Bandung.

Suprastini, 2018, PENGARUH MOTIVASI KERJA, KOMPETENSI, DAN KOMPENSASI TERHADAP KINERJA KARYAWAN MARKETING SALES PT TANABE INDONESIA, Jurnal, Jakarta.

Tanabe Indoensia, (2019). Trend Penjualan 2014-2019. Internal data. 